This is an Accepted Manuscript of an article published by Taylor \& Francis in Journal of Environmental Science and Health, Part A, Toxic/Hazardous Substances \& Environmental Engineering on 17/08/16, available online: http://www.tandfonline.com/doi/full/10.1080/10934529.2016.1215200. 


\title{
Relationship between air pollution and metal levels in cancerous and non-cancerous lung tissues
}

\section{ŁUKASZ J. BINKOWSKI ${ }^{1 *}$, PAWEŁ ROGOZIŃSKI ${ }^{2}$, MARTYNA BŁASZCZYK ${ }^{1}$, MAGDALENA SEMLA ${ }^{1}$, PATRICK MELIA ${ }^{3}$ and ROBERT STAWARZ ${ }^{1}$}

\author{
${ }^{1}$ Institute of Biology, Pedagogical University of Cracow, Poland \\ ${ }^{2}$ Department of Thoracic Surgery, Pulmonology and Thoracic Surgery Center, \\ Bystra, Poland \\ ${ }^{3}$ School of Life Sciences, Pharmacy and Chemistry, Kingston University, UK
}

\footnotetext{
*Address correspondence to Łukasz J. Binkowski, Institute of Biology, Pedagogical University of Cracow, Poland; Phone: +48126626724;

E-mail: 1jbinkowski@gmail.com
} 


\section{ABSTRACT}

We aimed to check the relationships between levels of metals $(\mathrm{Ca}, \mathrm{Cd}, \mathrm{Cu}, \mathrm{Fe}, \mathrm{Hg}$ and $\mathrm{Zn}$ ) in cancerous and non-cancerous lung tissues and their link to air pollution, expressed as particulate patter (PM) concentrations. The study also examines the influence on metal concentration in the lung tissue of patients' sex and the distance of their homes from the nearest emitter. We found that the general pattern of ascending concentrations in tumor tissue was as follow: $\mathrm{Hg}<\mathrm{Cd}<\mathrm{Cu}<\mathrm{Ca}<\mathrm{Zn}<\mathrm{Fe}$. In nonaffected lung tissue the order of concentrations of $\mathrm{Ca}$ and $\mathrm{Fe}$ was reversed. With the exception of $\mathrm{Cd}$ and $\mathrm{Cu}$, levels of metals were found in higher accumulations in noncancerous tissue (e.g. Fe 326.423 and Ca $302.730 \mu \mathrm{g} / \mathrm{g}$ d.w) than in tumorous tissue (Fe 150.735 and $\mathrm{Ca} 15.025 \mu \mathrm{g} / \mathrm{g}$ d.w). Neither the PM10 (PM of a diameter of $10 \mu \mathrm{m}$ ) concentration nor sex revealed any connection with metal concentrations. The shorter the distance from the emitter, the higher the metal concentrations that tended to be observed for almost all metals, but a statistically significant (but weak) relationship was noted only for $\mathrm{Cu}$ in tumor tissue $\left(\mathrm{r}_{\mathrm{s}}-0.4869\right)$.

Keywords: metal; copper; air pollution; cancer; biomonitoring

\section{INTRODUCTION}

Since the industrial revolution, a considerable increase in anthropogenic air pollution has been noted. Among the polluting substances, dangerous to human health are

particulate matter (PM) which includes metals, as among others $\mathrm{Cd}$ and $\mathrm{Hg}^{[1,2]}$ along 
with other substances and compounds. A characteristic feature of PM, suspended dust with an electrostatic dry, dust ventilation, is the range of variation in its chemical composition and scale of diverse size fractions. ${ }^{[3]}$ Frequent emission of PM10 (particulate matter of a diameter of $10 \mu \mathrm{m}$ ) is associated mainly with combustion, road transport and the urban sprawl. Many studies show that suspended dust in urban air has a significant impact on human health and may increase the risk of stroke, cardiovascular diseases and respiratory diseases. It may also be a significant risk factor for lung cancer and cancerogenesis. ${ }^{[4-7]}$

Lung cancer is the major cause of cancer mortality around the world. This is also the most common cancerogenic disease since 1985 and since then the number of cases has increased by $51 \%$. The disease is more predominant among smokers, but also other factors, as air pollution, occupational exposure and diet may increase the risk of the disease. ${ }^{[8-9]}$ Silesia is one of the most polluted areas in Poland and a high incidence of cancer has been noted among its inhabitants. The cause of the cancer rate in the area is still not fully confirmed, but the link to environmental pollution is suspected. ${ }^{[10-11]}$ Anthropogenic emissions, including energy and industrial production are the main source of air pollution in Silesia where the highest number of point sources are to be found in Poland. The PM10 level in Silesia is high and shows variability depending on the meteorological conditions and degree of urbanization. ${ }^{[12]}$ The varying fraction size of dust released from emitters also causes a variation in the distance the emissions may travel. ${ }^{[3]}$

Epidemiological evidence of the relationship between lung cancer and exposure to metallic compounds may be found in the literature. ${ }^{[13-15]}$ Metal contents in lung tumors may, moreover, be different from those in non-cancerous tissue. Assessing the impact of PM10 exposure on metal concentrations in both cancerous and non- 
cancerous tissue types therefore would appear to be of utmost importance. There is, however, no comprehensive evaluation of the possible association between these factors for cancerous and non-cancerous lung tissue. Since we also know that the PM10 concentrations may vary geographically, the other potential link to sources of air pollution (e.g. distance from the emitter) to lung tissue investigations should be taken into account. Our studies address this lack of research and verify the connection mentioned.

The major aim of the research was to estimate the concentrations of common metals, such as calcium $(\mathrm{Ca})$, cadmium $(\mathrm{Cd})$, copper $(\mathrm{Cu})$, iron $(\mathrm{Fe})$, mercury $(\mathrm{Hg})$ and zinc $(\mathrm{Zn})$, in cancerous and non-cancerous lung tissue in patients from Silesia. We evaluated the differences in metal concentrations according to tissue type, the sex of the patient and PM10 pollution in the area the patient lived. We also verified the relationship between the levels of metals examined and the distance from the nearest emitter, as well as the relationships in concentrations between metals and tissues.

\section{MATERIALS AND METHOD}

The patients $(n=56)$ whose data were used in the study were patients of the Pulmonology and Thoracic Surgery Center in Bystra, Poland. They represented two study groups: one suffering from lung cancer ( $n=42$; non-small cell lung cancer) and the other (the control) suffering from non-cancerous pulmonary disease (i.e. chronic obstructive pulmonary disease, tuberculosis, idiopathic pulmonary fibrosis; $n=14$ ). Some patients were smokers, but they were spread evenly among studied groups. None of the patient was exposed to PM or metals occupationally. All the patients live 
in the Silesia region which is heavily urbanized and highly populated area. The main source of PM10 air pollution here is the energy industry, emission from the residential sector, agriculture and emissions from road transport.

\section{Samples and analytical procedure}

All the samples were collected between 2013 and 2014 in the hospital while the patients were being treated. Patients with non-cancerous disease gave lung tissue samples during biopsy. Patients suffering from cancer gave samples of tumors and of adjacent non-affected tissue during surgery. After the samples were collected, some parts were sent for pathological analyses (unconnected with this study) and the rest were used in metal assessment protocol. Those samples were stored at a temperature of $-20^{\circ} \mathrm{C}$.

The concentrations of the metals, $\mathrm{Ca}, \mathrm{Cd}, \mathrm{Cu}, \mathrm{Fe}$ and $\mathrm{Zn}$, were measured in ca. $2 \mathrm{~g}$ of wet weight, firstly oven-dried $\left(60^{\circ} \mathrm{C}, \mathrm{SUP}-100 \mathrm{~W}\right.$ dryer, WAMED), then mineralized with hot nitric acid (65\%, Baker Analyzed, JT Baker) in the open mineralization system (Velp Scientifica DK20). Mineralized solutions were diluted with ultrapure water (18.2 $\mathrm{M} \Omega \cdot \mathrm{cm}$ at $25^{\circ} \mathrm{C}$, Direct-Q 3, Merck-Millipore) up to $10 \mathrm{~mL}$ and analyzed with a flame atomic absorption spectrometer (AAnalyst 200, PerkinElmer). The final results, after comparison with the limits of quantification and recalculations, were

presented as $\mu \mathrm{g}$ of metal per $1 \mathrm{~g}$ of the dry sample ( $\mu \mathrm{g} / \mathrm{g} \mathrm{d}$.w.). Hg measurements were taken in the automated $\mathrm{Hg}$ analyzer (NIC MA-2) without the external mineralization in ca. $100 \mathrm{mg}$ of each sample (with two repetitions). The initial $\mathrm{Hg}$ results were obtained in $\mu \mathrm{g} / \mathrm{g}$ wet weight, but they were then recalculated and also expressed as 
$\mu \mathrm{g} / \mathrm{g}$ d.w. ${ }^{[16]}$ The whole procedure was checked against the certified reference material analysis (Table 1).

\section{External data}

We investigated the connection between the distance from a patient's place of residence to the nearest big emitter, such as a mine or smelter, and metal concentrations in the patient's tissues. The distance was calculated as the straight line between the two points on a map.

Data regarding the concentrations of PM10 in the air where patients lived were taken from the system of air quality monitoring carried out by the Regional Inspectorate for Environmental Protection in Katowice. ${ }^{[17]}$ In accordance with that we have distinguished five classes of PM10 (metric tons per year: 2-100; 101-155; 156-220; 221-410 and 411-3690) in the area studied and in further statistical analysis we evaluated the influence of the PM10 factor on the concentrations found in the tissue studied.

\section{Statistical analysis}

The distribution of the data and variance homogeneity among the study groups were checked with the Shapiro-Wilk and Levene tests. ${ }^{[18]}$ Since deviations from the assumptions were observed, factorial ANOVA on ranks were carried out. ${ }^{[19]}$ The relationships between metal concentrations and other parameters were tested with the Spearman correlation analysis $\left(\mathrm{r}_{\mathrm{s}}\right)$. In all the statistical tests, the significance level was 
set at 0.05 . All the calculations and analyses were performed with StatSoft Statistica 10 EN and Microsoft Excel 2016 EN for Mac.

\section{RESULTS}

All the metals were found in both tissue types examined. Values lower than the limit of quantifications were observed in the frequencies: $12 \%$ for $\mathrm{Ca}, 8 \%$ for $\mathrm{Cd}, 4 \%$ for $\mathrm{Cu}, 0 \%$ for $\mathrm{Fe}, 6 \%$ for $\mathrm{Hg}$ and $3 \%$ for $\mathrm{Zn}$. PM10 and sex factors revealed no connection with metal concentrations (Table 2). On that basis, the data were polled and the results were presented without the division. Additionally, since there were no differences in metal concentrations in non-affected lung tissue between patients from the group suffering non-cancerous diseases and the group suffering from cancer (the Mann Whitney test, the lowest $\mathrm{p}$ was noted for Fe 0.2070), all the non-tumor data (non-affected tissue) were used in the comparison with the tumor tissue.

\section{Metal concentrations}

The general scheme of ascending concentrations in tumor tissue was as follow: $\mathrm{Hg}<$ $\mathrm{Cd}<\mathrm{Cu}<\mathrm{Ca}<\mathrm{Zn}<\mathrm{Fe}$. A similar trend was noted in the case of non-affected lung tissue with the exception of $\mathrm{Ca}$ whose median concentration was higher than the $\mathrm{Zn}$ level (Table 2). Concentrations of $\mathrm{Ca}, \mathrm{Cu}, \mathrm{Fe}$ and $\mathrm{Hg}$ differed significantly between tumor tissue and non-affected tissue ( 
Table 3). Higher levels were generally noted in non-affected lung tissue, with the exception of $\mathrm{Cu}$ whose concentrations were higher in tumorous samples. Of all the metals studied Fe achieved the highest median levels in both tissue-types tested (150.740 $\mu \mathrm{g} / \mathrm{g}$ d.w. for tumor and $326.42 \mu \mathrm{g} / \mathrm{g}$ d.w. for non-affected lung). Unlike Fe, the median concentrations were the lowest for $\mathrm{Hg}(0.0203 \mu \mathrm{g} / \mathrm{g}$ d.w. and $0.0340 \mu \mathrm{g} / \mathrm{g}$ d.w. for tumorous and non-affected tissues, respectively).

\section{Correlations between metals tested and distances from emitters}

For all the metals studied (with the exception of $\mathrm{Ca}$ and $\mathrm{Fe}$ in tumor) negative trends regarding the distance to the nearest emitter were observed, but almost all of them were statistically insignificant (

Table 3). The only significant, but still weak relationship occurred for $\mathrm{Cu}$ concentrations in tumor tissues $\left(\mathrm{r}_{\mathrm{s}}-0.4869, \mathrm{p}<0.05\right.$, Figure 1 , Table 3$)$.

Statistically significant correlations of metal concentrations between tissues were observed (Table 4). The strongest relationships were detected in $\mathrm{Cu}$ and $\mathrm{Zn}$ concentrations in tumors $\left(\mathrm{r}_{\mathrm{s}} 0.5449\right)$. We also noted a significant, but weak correlation of $\mathrm{Hg}$ concentrations between cancerous and non-cancerous tissue $\left(\mathrm{r}_{\mathrm{s}} 0.3811\right)$.

\section{DISCUSSION}

We found that neither sex nor PM10 were differentiating factors in the metal concentrations in tumor tissue and non-affected lung tissue. Despite this, we observed 
the negative correlation between environmental pollution (expressed as the distance of the nearest emitter to the patient's city of residence) and $\mathrm{Cu}$ concentrations in tumors. In other cases, similar trends, albeit statistically insignificant, were noted. We also observed several relationships between the concentrations of metals in tissues studied.

\section{Air pollution and metals}

Since we know that mining and manufacturing have been major industrial activities in Silesia for several decades, the contamination of this region with various pollutants is of special importance. ${ }^{[20-21]}$ We also know that air pollution may be harmful to people's health. Generally, women are more susceptible than men to the harmful influence of air quality on respiratory health. It is not yet well explained whether observed distinctions are attributable to biological differences (e.g. hormonal composition), differences in exposure (e.g. occupational) or to a combination of the two. ${ }^{[22]}$ Our results did not support these hypotheses, since we reported no differences between gender groups of patients studied.

An imbalance in the homeostasis of metals may generate reactive oxygen species (ROS) production leading to oxidative stress, and consequently cause pathological conditions. ${ }^{[23-24]}$ Since we know that Fe may be involved in tumor initiation and that Zn supported tumor growth, we suppose that the levels of these metals could be higher in the tissue before a tumor is diagnosed. ${ }^{[25-26]}$ Some investigations have confirmed that high Fe levels in breast tissue positively correlate with an impending risk of cancer. ${ }^{[27]}$ Declining $\mathrm{Zn}$ concentrations were also seen in malignant lung tissue when compared to non-affected tissue. ${ }^{[28]}$ This may explain the observation of higher $\mathrm{Fe}$ and $\mathrm{Zn}$ levels in lung tissue. We also suppose that higher $\mathrm{Ca}$ levels in the non- 
affected tissue studied may be linked with subsequent cancer development because $\mathrm{Ca}^{2+}$ overload induces mitochondrial dysfunction, as well as increasing ROS production and cellular damage. ${ }^{[29]}$ Transition metals such as $\mathrm{Hg}$ under pathological conditions additionally accumulate in target organs, lead to ROS generation and lipid peroxidation, promoting oncogenesis. ${ }^{[30]}$ This may explain the higher $\mathrm{Hg}$ concentrations detected in non-cancerous lung tissue, which is also consistent with other studies. ${ }^{[31]}$

Generally, we observed higher concentrations of metal (with the exception of $\mathrm{Cd}$ and $\mathrm{Cu}$ ) in non-affected lung tissue. Higher $\mathrm{Cu}$ levels in tumor tissue may be explained by the fact that $\mathrm{Cu}$-thionein may promote angiogenesis throughout the supplementation of $\mathrm{Cu}$ ions for enzymes involved in the formation of new blood vessels ${ }^{[32]}$ as one stage of the process of carcinogenesis. The mechanism of the accumulation of $\mathrm{Cd}$ in tumor tissue, already known in the literature, is unclear, but it may be linked with the increasing total accumulation according to age and the effect of cumulative exposure from various sources, such as environmental pollution, occupational exposure and lifestyle. ${ }^{[33-34]}$

\section{Correlations}

Negative weak trends between the levels of metals in non-affected and in cancerous lung tissue and distance from emitters were found. These results pointed to the tendency that the further from the source of pollution, the lower the metal levels detected. The same tendency has already been observed in plants and crabs. ${ }^{[34-35]}$ The strongest, but still weak correlation we observed linked the distance with $\mathrm{Cu}$ concentrations in tumor tissue (Figure 1). $\mathrm{Cu}$ is one of the main products of smelting 
and its concentrations in the tissues decrease as the distance from the source increases. ${ }^{[36]}$ This along with our observation may be very useful in biomonitoring, but one should bear in mind that emitters such as mines and smelters are not the only cause of air pollution. Today a great many point sources of air pollution exist, such as on-road mobile sources (e.g. cars and buses), non-road mobile sources (e.g. trains, aircraft,) and immobile sources (e.g. household coal boilers). All these carriers add to the general air pollution and affect organisms (including the stimulation of cancerogenesis). ${ }^{[37]}$ Factors such as occupational exposure or daily movement may influence the inference and the method may thus be useful for large areas, such as provinces or areas with a very few, but centralized emitters.

$\mathrm{Zn}$ plays a role in regulating $\mathrm{Cu}$ levels in the body which may explain the correlation we noted between them. ${ }^{[38]}$ Essential elements protect against intoxication by other metals, and this may explain the significant relationship between $\mathrm{Cd}$ and $\mathrm{Cu} .{ }^{[39]} \mathrm{We}$ also saw the positive correlations $\mathrm{Zn}-\mathrm{Fe}$ and $\mathrm{Zn}-\mathrm{Ca}$. Correlations between metals in the same organs may represent evidence of similar distribution of those metals throughout the system. ${ }^{[39]}$ Interestingly, Cobanoglu ${ }^{[40]}$ found a negative relationship between $\mathrm{Zn}$ and Fe levels in cancerous lung tissue, which contradicts Yoo's ${ }^{[39]}$ and our results.

We observed a significant, positive correlation between $\mathrm{Hg}$ levels in tumors and in non-cancerous tissue. Tumors grow inside the lung tissue and may even be considered to be changed tissue, so this could explain the relationship observed. This hypothesis, however, needs further examination. 


\section{CONCLUSIONS}

The study revealed that the PM10 factor seems to have no direct relationship with the levels of metal in the tissues studied. The tendency that the shorter the distance from the emitter, the higher the metal concentrations in target organs, however, was observed for copper in tumor tissue $\left(\mathrm{r}_{\mathrm{s}}-0.4870\right)$. Non-cancerous tissue seems to reach higher levels of metals in comparison with tumorous tissue. This may suggest that the metals studied, if found at elevated concentrations, may promote cancerogenesis and air contamination may be a co-factor behind cancerogenesis. The results also indicate the importance of the distance of the emitter as a tool in evaluating exposure, however a stronger relationship is to be observed for areas with very few, but centralized emitters, or large areas, such as provinces.

\section{ACKNOWLEDGEMENT}

We would like to thank all the patients who agreed to our using their samples and medical tests in the study. The project was carried out on the basis of the approval of the Bioethical Commission of the Medical University in Katowice (No. KNW/0022/ KB1/139/I/11/12).

\section{REFERENCES}


[1] Pastuszka J.S.; Wawroś A.; Talik E.; Paw U.K.T. Optical and chemical characteristics of the atmospheric aerosol in four towns in southern Poland. The Science of Total Environment 2003, 309(1-3), 237-251.

[2] Ukpebor J.E.; Ukpebor E.E.; Kadiri V.I.; Odiase J.I.; Okuo J.M.; Ogbeifun D. Atmospheric trace metal concentrations in suspended particulate matter (SPM) of a rural residential area in southern Nigeria. Ife Journal of Science 2012, 14(1), 1-14.

[3] Nowińska K.; Adamczyk Z. The mobility of accompanying elements to wastes from metallurgy of the zinc and the lead in the environment (Mobilność pierwiastków towarzyszących odpadom hutnictwa cynku i ołowiu w środowisku). Górnictwo i Geologia 2013, 8(1), 77-87.

[4] Chen H.; Goldberg M.S. The effects of outdoor air pollution on chronic illnesses. McGill Journal of Medicine 2009, 12(1), 58-64.

[5] Ravindra K.; Mittal A.K.; Van Grieken R. Health risk assessment of urban suspended particulate matter with special reference to polycyclic aromatic hydrocarbons: a review. Reviews on Environmental Health 2001, 16, 169-189.

[6] Uzoigwe J.C.; Prum T.; Bresnahan E.; Garelnabi M. The emerging role of outdoor and indoor air pollution in cardiovascular disease. North American Journal of Medical Sciences 2013, 5(8), 445-453.

[7] Valavanidis A.; Vlachogianni T.; Fiotakis K.; Loridas S. Pulmonary oxidative stress, inflammation and cancer: respirable particulate matter, fibrous dusts and ozone as major causes of lung carcinogenesis through reactive oxygen species mechanisms. 
International Journal of Environmental Research and Public Health 2013, 10(9), 3886-3907.

[8] Molina J.R.; Yang P.; Cassivi S.D.; Schild S.E.; Adjei A.A. Non-small cell lung cancer: epidemiology, risk factors, treatment, and survivorship. Mayo Clinic Proceedings 2008, $83,584-594$.

[9] Dela Cruz C.S.; Tanoue L.T.; Matthay R.A.M. Lung cancer: epidemiology, etiology and prevention. Clinics in Chest Medicine 2011, 32, 1-61.

[10] Kapka L.; Zemła B.F.; Kozłowska A.; Olewińska E.; Pawlas N. Air quality vs morbidity to lung cancer in selected provinces and localities of the Silesian region (Jakość powietrza atmosferycznego a zapadalność na nowotwory płuc w wybranych miejscowościach i powiatach województwa śląskiego). Przegląd Epidemiologiczny 2009, $63,439-444$.

[11] Mielżyńska D.; Siwińska E.; Kapka L., Eds. Mutagenicity of airborne particles as an indicator of air quality. Part A: Mutagenicity of airborne particles in Silesia province in 1999/2000. Institute of Occupational Medicine and Environmental Health: Sosnowiec, 2002; 1-91.

[12] IEP Inspection of Environmental Protection. The national mosaic report on the state of the environment - Silesian region (Krajowy raport mozaikowy o stanie środowiska - województwo śląskie). Katowice. Last access: 12.01.2016. http://www.katowice.pios.gov.pl/monitoring/raporty/2002-07/mozaika.pdf [13] Wild P.; Bourgkard E.; Paris C. Lung cancer and exposure to metals: the epidemiological evidence. Methods in Molecular Biology 2009, 472, 139-167. 
[14] Kuo C.Y.; Wong R.H.; Lin J.Y.; Lai J.C.; Lee H. Accumulation of chromium and nickel metals in lung tumors from lung cancer patients in Taiwan. Journal of Toxicology Environmental Health, Part A 2006, 69(14), 1337-1344.

[15] Binkowski Ł.J.; Rogoziński P.; Roychoudhury S.; Bruliński K.; Kucharzewski M.; Łaciak T.; Massanyi P.; Stawarz R. Accumulations of metals in cancerous and healthy tissues of patients with lung cancer in Southern Poland. Journal of Environmental Science and Health Part A 2015, 50, 9-15.

[16] Błaszczyk M.; Paluch J.; Binkowski Ł.J.; Rogoziński P.; Stawarz R. The relationships between dry and wet weight of lung and tumor tissues influenced by the drying procedure. Fresenius Environmental Bulletin 2016, 25(6), 1755-1759.

[17] SMAQ System of Monitoring Air Quality for PM10. Last access: 10.02.2015. http://powietrze.katowice.wios.gov.pl/

[18] Shapiro S.S.; Wilks M.B.; Chen H.J. A comparative study of various tests for normality. Journal of the American Statistical Association 1968, 63, 1343-1372.

[19] Quinn G.P.; Keough M.J. Experimental design and data analysis for biologists. University Press: Cambridge, 2002; 250.

[20] Dobrzański Z.; Kołacz R.; Górecka H.; Chojnacka K.; Bartkowiak A. The content of microelements and trace elements in raw milk from cows in the Silesian Region. Polish Journal of Environmental Studies 2005, 14(5), 685-689.

[21] Ryder R.W. Lead poisoning among children in Katowice, Poland. Physicians for Social Responsibility 1992, 2, 77-84. 
[22] Clougherty J.E. A growing role for gender analysis in air pollution epidemiology. Environmental Health Perspectives 2010, 118(2), 167-176.

[23] Koedrith P.; Seo Y.R. Advances in carcinogenic metal toxicity and potential molecular markers. International Journal of Molecular Sciences 2011, 12, 9576-9595.

[24] Birben E.; Sahiner U.M.; Sackesen C.; Erzurum S.; Kalayci O. Oxidative stress and antioxidant defense. World Allergy Organization Journal 2012, 5, 9-19.

[25] Yaghoubi S.; Barlow J.; Kass P.H. Breast cancer and metals: a literature review [Ph.D. thesis]. University of California: Davis, 2007.

[26] Zhang C.; Zhang F. Iron homeostasis and tumorigenesis: molecular mechanisms and therapeutic opportunities. Protein and Cell 2015, 6(2), 88-100.

[27] Cui Y.; Vogt S.; Olson N.; Glass A.G.; Rohan T.E. Levels of zinc, selenium, calcium and iron in benign breast tissue and risk of subsequent breast cancer. Cancer Epidemiology, Biomarkers and Prevention 2007, 16(8), 1682-1685.

[28] Engelken J.; Altmayer M.; Franklin R.B. The disruption of trace element homeostasis due to adeuploidy as a unifying theme in the etiology of cancer. bioRxiv 002105. DOI: http://dx.doi.org/10.1101/002105 Last access: 20.02.2016.

[29] Peng T.I.; Jou M.J. Oxidative stress caused by mitochondrial calcium overload. Annals of the New York Academy of Science 2010, 1201, 183-188.

[30] Ionescu J.G.; Novotny J.; Stejskal V.; Lätsch A.; Blaurock-Busch E.; EisenmannKlein M. Increased levels of transition metals in breast cancer tissue.

Neuroendocrinology Letters 2006, 27(1), 36-39. 
[31] Tran J.Q.; Dranikov A.; Iannucci A.; Wagner W.P.; LoBello J.; Allen J.; Weiss G.J. Heavy metal content in thoracic tissue samples from patients with and without NSCLC. Lung Cancer International 2014, article ID 853158, 1-6.

[32] Rydzewska A. A comparison of concentrations of heavy metals in neoplastic and perineoplatic lung tissues in inhabitants from Wielkopolska and Upper Silesian Industrial District in Poland. Polish Journal of Environmental Studies 2001, 10(4), 289-292.

[33] Janicka M.; Binkowski Ł.J.; Błaszczyk M.; Paluch J.; Wojtaś W.; Massanyi P.; Stawarz R. Cadmium, lead and mercury concentrations and their influence on morphological parameters in blood donors from different age groups from southern Poland. Journal of Trace Elements in Medicine and Biology 2015, 29, 342-346.

[34] Khlifi R.; Olmedo P.; Gil F.; Hammami B.; Chakroun A.; Rebai A.; Hamza Chaffai A. Arsenic, cadmium, chromium and nickel in cancerous and healthy tissues from patients with head and neck cancer. Science of the Total Environment 2013, $452-453,58-67$.

[35] Hosseini M.; Bastami A.A.; Khoei J.K.; Esmailian M.; Songhori E.J.; Najafzadeh M. Concentrations of heavy metals in selected tissues of blue swimming crab, Portunus pelagicus (Linnaeus, 1758) and sediments from Persian Gulf. World Applied Sciences Journal 2012, 19(10), 1398-1405.

[36] Eeva T.; Sorvari J.; Koivunen V. Effect of heavy metal pollution on red wood ant (Formica s. str.) populations. Environmental Pollution 2004, 132, 533-539. 
[37] Straif K.; Cohen A.; Samet J., Eds. Air pollution and cancer. IARC Scientific Publication 2013, no.161.

[38] Duruibe J.O.; Ogwuegbu M.O.C.; Egwurugwu J.N. Heavy metal pollution and human biotoxic effect. International Journal of Physical Sciences 2007, 2(5), 112-118.

[39] Yoo Y.; Lee S.; Yang J.; In S.; Kim K.; Kim S.; Kwon T.; Ko Y.; Chung K.

Distribution of heavy metals in normal Korean tissues. Problems of Forensic Sciences 2000, 43, 283-289.

[40] Cobanoglu U.; Demir H.; Sayir F.; Duran M.; Mergan D. Some mineral, trace elements and heavy metal concentrations in lung cancer. Asian Pacific Journal of Cancer Prevention 2010, 11, 1383-1388. 
Table 1. Characteristics of the analytical method used: limits of quantification (LoQ) in the mineralized solutions $[\mathrm{mg} / \mathrm{L}]$, recoveries for certified reference material (CRM) analyses $(n=11)$ with relative standard deviations (RSD) between replicates

\begin{tabular}{cccccc}
\hline Metal & Wave $\lambda[\mathrm{nm}]$ & LoQ & CRM $^{*}$ & Recovery [\%] & RSD [\%] \\
\hline $\mathrm{Ca}$ & 422.70 & 0.514 & SRM1577b & 100.3 & 2.1 \\
$\mathrm{Cd}$ & 228.80 & 0.010 & SRM1577b & 106.8 & 2.7 \\
$\mathrm{Cu}$ & 324.80 & 0.035 & SRM1577b & 92.2 & 1.3 \\
$\mathrm{Fe}$ & 248.30 & 0.415 & SRM1577b & 92.3 & 6.2 \\
$\mathrm{Hg}$ & 253.70 & $0.208^{*}$ & BCR-463 & 99.2 & 1.7 \\
$\mathrm{Zn}$ & 213.90 & 0.024 & SRM1577b & 108.1 & 2.4 \\
\hline
\end{tabular}

"LoQ value for $\mathrm{Hg}$ expressed as ng per sample.

${ }^{*}$ SRM1577b - bovine liver, National Institute of Standards \& Technology, USA; BCR-463 - tuna fish, Joint Research Centre, Institute for Reference Materials and Measurement, Belgium).

Table 2. Concentrations of metals ( $\mu \mathrm{g} / \mathrm{g}$ d.w.) and the significance of sex and PM10 factors (factorial ANOVA on ranks) in tumor and non-affected lung tissue of patients studied

\begin{tabular}{ccrrrrrrr}
\hline & $n$ & Median & Minimum & Maximum & $Q_{1}$ & $Q_{3}$ & $\begin{array}{r}\text { Sex } \\
\text { factor } p\end{array}$ & $\begin{array}{r}\text { PM10 } \\
\text { factor } p\end{array}$ \\
\hline Ca tumor & 36 & 15.025 & 0.000 & 377.767 & 0.000 & 76.167 & 0.2334 & 0.1563 \\
Cd tumor & 36 & 1.239 & 0.000 & 8.108 & 0.728 & 3.096 & 0.9023 & 0.4669 \\
Cu tumor & 30 & 9.151 & 3.700 & 18.633 & 7.819 & 11.239 & 0.4935 & 0.7413 \\
Fe tumor & 36 & 150.735 & 38.265 & 1021.244 & 97.497 & 220.476 & 0.9821 & 0.7579 \\
Hg tumor & 40 & 0.020 & 0.000 & 0.299 & 0.010 & 0.034 & 0.3374 & 0.4137 \\
Zn tumor & 36 & 77.382 & 0.000 & 233.449 & 58.602 & 93.511 & 0.1808 & 0.2107 \\
\hline Ca lung & 38 & 302.730 & 53.557 & 6420.290 & 142.765 & 660.225 & 0.6720 & 0.3036 \\
Cd lung & 38 & 1.084 & 0.000 & 11.111 & 0.160 & 3.182 & 0.2696 & 0.2559 \\
Cu lung & 38 & 5.474 & 0.000 & 49.684 & 4.680 & 6.960 & 0.4030 & 0.9122 \\
Fe lung & 38 & 326.423 & 105.378 & 3251.029 & 217.729 & 571.977 & 0.3129 & 0.2925 \\
Hg lung & 53 & 0.034 & 0.000 & 0.606 & 0.027 & 0.046 & 0.5863 & 0.5310 \\
Zn lung & 38 & 79.990 & 29.576 & 204.545 & 60.927 & 99.849 & 0.3873 & 0.3107 \\
\hline Q1-lower quartile, $Q_{2}-$ higher quartile. & & & & &
\end{tabular}


Table 3. The differences in metal concentrations between tumor tissue and nonaffected lung tissue (Mann Whitney test; $p$ ) in the population studied and the correlations between metal concentrations and distance from the emitter (Spearman correlation $\mathbf{r}_{\mathbf{s}}$ )

\begin{tabular}{cr|rr}
\hline & $\begin{array}{r}\text { Tumor vs lung } \\
\text { concentrations } p\end{array}$ & $\begin{array}{r}\text { Distance with tumor } \\
\text { concentrations } r_{s}\end{array}$ & $\begin{array}{r}\text { Distance with lung } \\
\text { concentrations rs }\end{array}$ \\
\hline $\mathrm{Ca}$ & $\leq 0.0001$ & 0.1452 & -0.1032 \\
$\mathrm{Cd}$ & 0.6302 & -0.0596 & -0.2018 \\
$\mathrm{Cu}$ & $\leq 0.0001$ & -0.4870 & -0.1353 \\
$\mathrm{Fe}$ & $\leq 0.0001$ & 0.0389 & -0.1529 \\
$\mathrm{Hg}$ & $\leq 0.0001$ & -0.0047 & -0.0907 \\
$\mathrm{Zn}$ & 0.7610 & -0.2966 & -0.0146 \\
\hline Underlining indicates statistically significant differences and correlations.
\end{tabular}

Table 4. Significant Spearman correlations $\left(r_{s}\right)$ between metal concentrations in tissues studied

\begin{tabular}{rr}
\hline Correlation & rs $_{\text {Ca lung vs Zn lung }}$ \\
\hline Ca tumor vs Cd tumor & 0.4264 \\
Cu tumor vs Zn tumor & 0.4411 \\
Fe lung vs Zn tumor & 0.5449 \\
Hg lung vs Hg tumor & 0.3811 \\
\hline
\end{tabular}




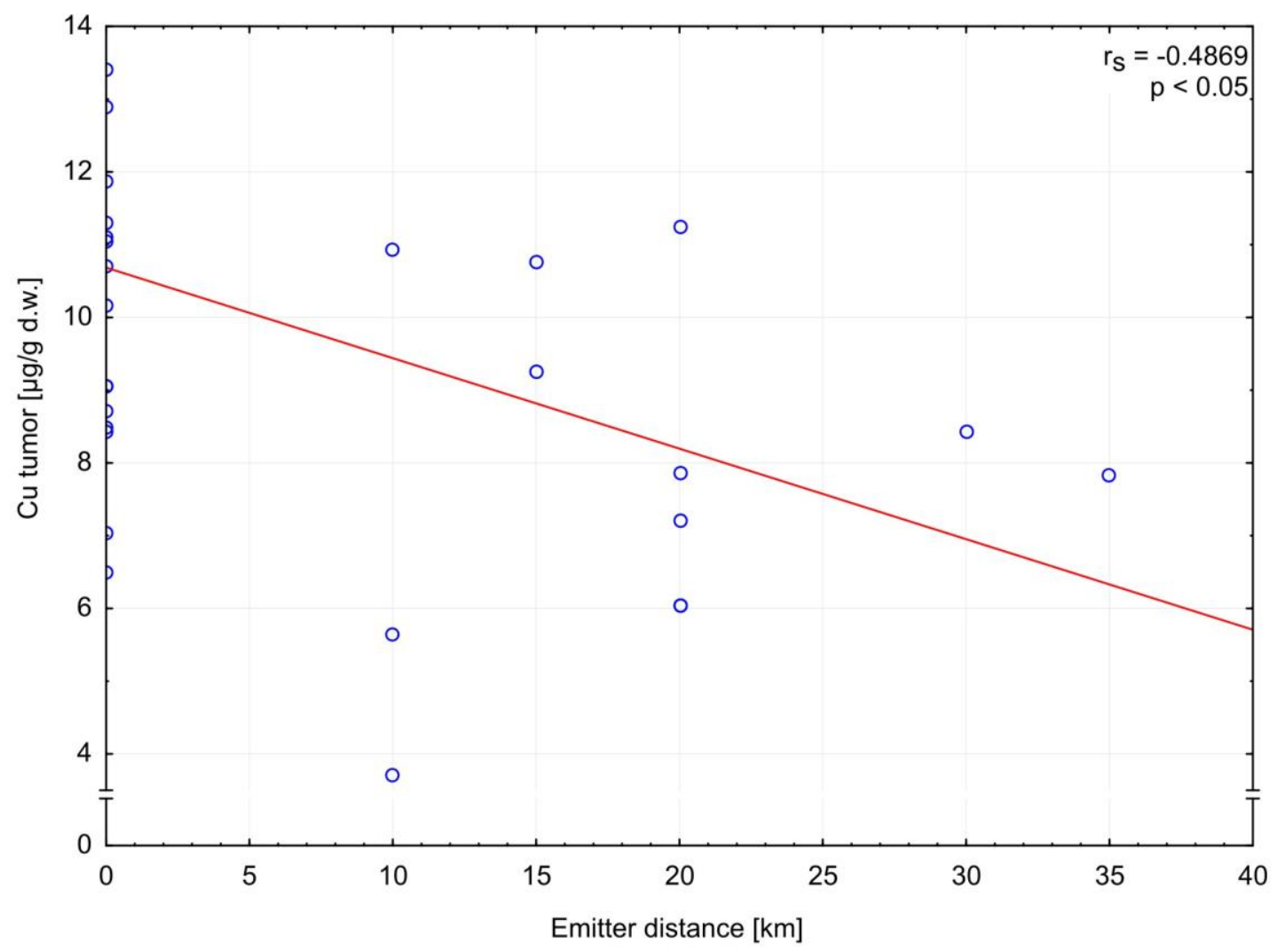

Figure 1. 


\section{FIGURE CAPTION}

Figure 1. Statistically significant correlation between levels of copper in tumor tissue and distance from the nearest emitter. 